\title{
Perfect food: perspectives on consumer perceptions of fresh produce quality
}

\author{
CAITLIN FINLAYSON
}

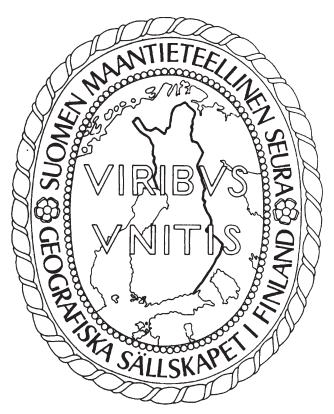

Finlayson, C. (2018) Perfect food: perspectives on consumer perceptions of fresh produce quality. Fennia 196(2) 168-186. https://doi.org/10.11143/ $\underline{\text { fennia.65645 }}$

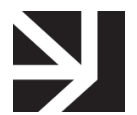

Over the past century, the global food system has largely shifted from a localized, decentralized agricultural model to more centralized, industrial food production system. Corresponding with this shift was a change in consumer preferences, an expectation for "perfect" fruits and vegetables that has contributed to a significant problem with wasted food. An alternative food system, aimed at providing locally-grown, sustainable produce has countered this model and has sought to reconnect consumers and producers. At the same time, this alternative model still exists within a larger agricultural system dominated by industrial production and standardization. This paper examines how the changes in the ways consumers look at fresh produce quality has affected the practices of retailers and drives food waste at the supply chain using in-depth interviews conducted in a variety of settings in Fredericksburg, Virginia, USA. An analysis of these interview findings reveals that even in alternative food buying locations, consumers have a general expectation of perfection but that as consumers build relationships with the people who grow their food, these perceptions, and our food waste practices, might be changed.

Keywords: food geography, environmental geography, agriculture, farmers markets

Caitlin Finlayson, University of Mary Washington, 1301 College Avenue, Fredericksburg,VA, USA 22401.E-mail: cfinlay@umw.edu

\section{Introduction}

Every year in the United States alone, $40 \%$ of food is wasted, much of it edible and nutritious but simply not in line with consumer food preferences (Gunders 2012). If Americans were able to save even $15 \%$ of the food that is commonly thrown out, it would be enough to feed 25 million people each year (Gunders 2012). The consumer preferences driving this tremendous waste, particularly the preference for "perfect" fruits and vegetables, that is, fruits and vegetables that are symmetrical in color and shape, is reshaping our agricultural practices and is changing our landscape. While our agricultural system used to be highly localized supporting a wide variety of crops, the industrial model has come to dominate globally (Barker 2007), a model where standardization and perfection are privileged above sustainability and diversity. Coupled with this shift has been a corresponding change in consumer preferences where the perfection demanded by industrial factory production has now become the accepted consumer standard (Godfray et al. 2010; Gustavsson et al. 2011; Gunders 2012). As the industrial agricultural model has come to dominate in the United States in particular, alternative food systems have developed that seek to reconnect consumers with the producers of their foods in a Creative Commons Attribution 4.0 International License. 
places like farmer's markets and consumer-supported agricultural organizations (Watts et al. 2005; Kneafsey et al. 2008). While these systems provide for re-localization and more sustainable growing and waste management practices, as this paper explores, the produce they provide does not always meet the exacting standards now expected by consumers.

This paper explores how food retailers, to include supermarkets and alternative food vendors, market and display foods in response to consumer buying practices while at the same time, shaping and reshaping consumer preferences. In-depth interviews conducted with alternative and more traditional food vendors in Fredericksburg, Virginia, USA reveal that consumer perception of produce quality, while not entirely dependent on geography, can be shifted and adapted based on the relationship they build with their supplier or grower. As we have moved away from a model of agriculture that directly links consumers with growers, we have seen a subsequent increase in food waste and a reliance on off-farm inputs like fertilizers and pesticides to maintain an artificial level of perfection that is not typically found in nature (Horrigan et al. 2002). Just as this transition has impacted consumer perception, consumer preferences have had a profound environmental effect. These interviews also point to the potential for alternative food systems to reshape consumer expectations as producers and growers work with consumers to educate them on the challenges of growing food sustainably. Broadly, this paper seeks to address calls for the discussion of the interconnected nature of alternative food models and their embeddedness within the larger industrial agricultural system (Sonnino 2016).

For geographers, this is, pun intended, fertile ground. The subject of food waste, particularly the amount of food wasted in the United States, has received considerable media attention: a Google News search of "food waste" elicits over 47 million results (Nixon 2015; Goldenberg 2016; Sengupta 2017; Mooney 2018). At the same time, the topic has received relatively little attention by geographic researchers (see Royte 2016 for a rare exception), particularly with regard to how individual consumer preferences drive large-scale retail and agricultural practices. Space matters, location matters, and how we look at food is largely dependent upon geography. As developed countries have transitioned to an industrial agricultural model, the way we look at food and what we consume has changed. Whereas locally-grown, seasonal foods were formerly the norm, many of those in industrialized countries now have access to a wealth of fruits and vegetables year-round and spend far less time in the kitchen preparing foods than in the past (Regmi 2001). Fruit and vegetable consumption is highest among higher-income countries and has increased in the United States over the past several decades (Pollack 2001). Further, improvements in packing and shipping technology have enabled fruits and vegetables to travel long distances while still maintaining their "perfect" appearance (Pollack 2001). Even as alternative food systems have expanded, an analysis of the interviews conducted for this paper demonstrates that the perfection we have come to expect from the industrial model has become the standard for what we expect even at alternative food purchasing locations. Adjusting these expectations, and understanding why imperfections are present within alternative food growing practices, could have a dramatic effect on food growing practices and the amount of food that is ultimately wasted.

\section{Transitions, disconnections, and reconnections}

Historically, food production was a highly localized, decentralized process, and was thus highly geographical in nature. Local communities sought efficient ways of producing food given their geographic constraints of climate, soil, water availability, and so on. As Barker (2007) explains, highly specialized agricultural systems evolved in specific locales over thousands of years. Furthermore, "all of these successful adaptations resulted from farmers' intimate relations with the land, weather conditions, and unique local conditions" (Barker 2007, 6). Thus, for most of human history, nature, farming, and eating were all closely linked. These locally-centered food systems supported an array of diverse crops and growing methods, as well as a culture of food (Barker 2007).

Over the past century, however, a dramatic shift has occurred in the way we approach food production. Rather than relatively small farms growing specialized foods for their own communities, there has been a global shift towards a centralized, industrial agricultural system, replacing the 
localized food systems that were previously intertwined with traditional cultures and local ecosystems (Barker 2007). The geography of food has thus become less a study of local cultures and adaptations and more an examination of broad patterns of industrialization and globalization. These changes in food production and consumption are largely a function of income (Gehlhar \& Coyle 2001) and urbanization (Regmi \& Dyck 2001), with locally-grown, seasonal crops maintaining primary importance in lower-income countries (Pollack 2001). In higher-income countries like the United States, however, locally grown specialties of fruits and vegetables, for example, have been replaced by standardized hybrid varieties (Fernandez-Cornejo 2004). In such a system where local geography is marginalized in favor of uniformity, standardization, and profits, off-farm inputs such as chemical fertilizers and pesticides are necessary. Not surprisingly, then, fertilizer use increased an astounding $400 \%$ per person from 1950 to 1998 (Horrigan et al. 2002). Other inputs such as water and fossil fuels are also significantly higher in such a system. "The food production system accounts for $17 \%$ of all fossil fuel use in the United States" and additional fossil fuels are also needed to bring the foods to markets in such a centralized food production scheme (Horrigan et al. 2002, 448).

Yet, despite this shift toward a more concentrated, industrial agricultural model, almost 900 million people worldwide go hungry each day and around 40 people die of hunger each year (Barker 2007). Hunger and extreme poverty are closely linked, with food insecurity a symptom of poverty, and though impressive strides have been made at reducing global poverty, poverty and food insecurity persist in Sub-Saharan Africa where the number of people not getting enough food has actually increased almost 25\% since 1990 (Sharma et al. 2016). Even though there is more than enough food to feed everyone were it evenly distributed (Barker 2007), it would seem that the transition to industrial agriculture has not dramatically improved global food security. Particularly in the developing world, perhaps because the corporations that control food production and access "have been able to control the rules of the system" (Barker 2007, 2). Furthermore, "industrial food production methods - and some of the foods they produce - are also causing both acute and chronic disease in humans" (Horrigan et al. 2002, 449). Pesticide use, for example, which increased substantially with the rise of industrial agriculture, leaves residue on foods that can increase the risk of cancers (Horrigan et al. 2002).

The speed at which we process our foods, particularly meat products, increases our risk of acquiring foodborne illnesses (ibid. 2002). Why would global consumers accept such a trade from locally grown, sustainable products, to an industrial model that is, by most measures, worse? Perhaps a better question to answer would be who has benefitted from such a transition? Agribusinesses, who have continued to consolidate and increase profits, have partnered with government institutions and international trade organizations to negotiate global agreements and set agricultural policy while at the same time, remaining the "primary beneficiaries" of the industrial agricultural system (Barker 2007 , 6). Consumers, too, have benefitted, with people in higher income countries spending a lower proportion of their income on food due to industrial production methods that reduce costs (Regmi et al. 2001). These higher incomes also enable consumers in more developed countries to access a wider variety of foods than would otherwise be available as a result of domestic production systems and global trade (Pollack 2001).

At the same time, alternative food systems, that is, food systems which counter the industrial agricultural model, have expanded in recent decades. The number of farmers' markets across the United States, for example, has increased substantially in the past few decades, from just over 2,400 in 1996 to over 8,600 in 2016 (USDA-AMS-Local Food Research \& Development Division 2016). Across Europe, "farmers' markets" are relatively new, with the first modern farmers' market opening in Bath, England in 1997 (Vecchio 2009). Direct selling of agricultural products to consumers by farmers is not a recent creation and has existed in a variety of forms, but the popularity of modern farmers' markets grew out of a reaction against industrial agriculture and a desire amongst consumers to gain access to fresh and local food products (Vecchio 2009). Broadly, these alternative food systems are characterized by shorter distances between producers and consumers, smaller farms and organic or holistic farming methods, food purchasing venues that exist outside of traditional commercial establishments, and a commitment to sustainability at all levels of production, distribution, and consumption (Jarosz 2008). 
Explorations of these alternative food systems, particularly farmers' markets, have factored prominently in geographic literature. Farmers' markets, community supported agricultural (CSA) organizations, and other alternative food purchasing locations exist as spaces of performance, and their performative element remains a key area of investigation. Alkon and McCullen (2011), for example, explored the alternative agrifood movement in northern California, USA, finding that it is largely comprised of relatively affluent, white shoppers, but that these spaces have the potential to contribute to a larger discourse of social and racial justice and sustainability (see also Slocum 2006; Guthman 2008a, 2008b). Reynolds (2015) similarly found racial and economic injustices inherent in the urban agricultural system of New York City. Slocum (2008) approached the racial divisions of alternative food systems from a feminist materialist perspective, exploring how race is embodied within the space of the farmers' market.

Other geographers have taken a broader view, investigating wider patterns of consumer behavior rather than individual performances. Brown (2001) examined farmers' market trends within the United States over the past few decades finding considerable growth but also a distinct lack of reliable data. Many of the geographic research into farmers' markets and alternative food systems not surprisingly employed mapping and GIS techniques. Kremer and DeLiberty (2011), for example, mapped the local food system in Philadelphia finding that slightly over half are located in medium to high income neighborhoods and that a sizeable amount of land in the city could be utilized for food production. Consumer patterns at these locations are not just spatial, however, and researchers like Mack and Tong (2015) have explored farmers' markets from a temporal dimension as well, finding that shoppers at farmers' markets take market operating time into account, not just the geographic location of the site. In this way, geographers might consider alternative food system accessibility a function of both space and time. Feagan (2007) took a more theoretical approach to the broader study of alternative food, "mapping" the very meaning of the term "local" and how it is approached in food systems literature from a geographic perspective. Watts, Ilbery, and Maye (2005) similarly approached the notion of "alternativeness" from a theoretical perspective informed by economic geography. Other researchers have explored issues of sustainability (Feenstra 1997; Feagan et al. 2004), including understanding how local alternative food systems can be sustainability created (Feenstra 2002).

Most of the research in the area of food production and food waste are not explicitly geographical and focus on food waste policy (Hodges et al. 2011; Sonnino \& McWilliam 2011; Lipinski et al. 2013; Calvo-Porral et al. 2017) or examine the sociology of food waste (Edwards \& Mercer 2012; Watson \& Meah 2012). Evans (2012), for example, offered a sociological investigation of household food waste, exploring how the home and our domestic activities within it serve to socially and materially organize our interactions with food. De Hooge and others (2017) similarly found that different factors influenced consumer's likelihood to buy imperfect foods in the supermarket versus the home. Geographers can expand on this research, explicitly exploring how our interactions are spatially mediated, with the ways we interact with food, and food waste, changing depending on our location. Food regime theory has also emerged as a key theoretical foundation for food waste discourse, approaching the various transitions in food systems as a complex change in regimes, meaning shifts in politics, governance, trade, consumer culture, and so on (Campbell et al. 2017).

As Winter (2003) notes, research into the geography of agriculture has shifted in recent decades toward an emphasis on reconnecting concepts like food, farmers, and nature that were previously examined in isolation. As part of this reconnection, this paper proposes an increased attention to the ways in which these reconnections are being embodied at the local level. Reconnecting people to the spaces where their foods are grown and to the people who grow them is, in many ways, a fundamental feature of alternative food systems. Bell and Valentine (1997)'s Consuming Geographies: We Are Where We Eat posits that the locations where we consume foods serve as spaces of social production and reproduction. Indeed, but we are where we shop, as well, with the spaces where we buy our foods producing and reproducing our social values. Alternative food spaces are thus positioned to be spaces of contestation, opposing the prevailing values of agribusiness while at the same time existing in a world that has been created by them. Further, if we primarily now shop in retail spaces for our foods, rather than growing them ourselves, then the perceptions retailers have of our preferences becomes significant. Retail analysts maintain that "freshness is the most important driver of customer satisfaction 
with a store's produce" and that produce sales increase sales volume store-wide (Bacos et al. 2014, 3). It should be noted, however, that the notions of quality and freshness are difficult to define but are largely based on "visual, aural, textural and taste sensations [which are] culturally mediated" (Watts et al. 2005, 29). Alternative food spaces are largely positioned as purveyors of fresh, quality produce, as our interview findings demonstrate (Watts et al. 2005), and provide an opportunity for consumers to reconnect with the process of growing foods and develop relationships with their suppliers. Geographers are well-positioned to explore these spaces of performance, transition, and reconnection, locations that seek to re-localize an agricultural model that was once highly place-dependent.

While scholarship on alternative food systems has shed much-needed light on the injustices inherent even in non-mainstream food purchasing locations and on their spatial distribution, these studies are largely compartmentalized, offering stand-alone case studies rather than a broader spatial analysis of the food system as a whole. As Sonnino $(2016,8)$ notes, "much of the theoretical discussion has focused on understanding the 'alternativeness' of local food initiatives in relation to the conventional dynamics that have been shaping the global food system". Discussions regarding the interconnected nature of alternative food systems or their broader effects on regional agricultural development remain marginalized (Sonnino 2016). With the exception of a National Geographic article spotlighting ugly food, its effect on food waste and potential to address food insecurity (Royte 2016), geographers continue to be largely absent from a broader discourse on how food waste impacts and is impacted by geography. This paper seeks to specifically address this issue by exploring how various food purchasing locations contribute to or mitigate food waste as well as the intersection of industrial agriculture, alternative food systems, and consumer perceptions.

\section{Alternative food systems and the geography of food waste}

While the various investigations of alternative food systems are helpful in understanding how they serve as a reaction to industrial agriculture, geographers have largely been absent from an analysis of how food waste practices at the point of purchase are spatially mediated. If it is true that "we are what we eat," then what can be said of what we do not eat? As we have transitioned from a traditional, local agricultural model to an industrial model dominated by agribusinesses, our food waste practices have simultaneously changed. The Food and Agricultural Organization (FAO) of the United Nations estimates that around one-third of all edible parts of foods produced for human consumption are wasted or lost each year (Gustavsson et al. 2011). Although causes of this food waste vary by country, the FAO states that in general, "the causes of food losses and waste in medium/high-income countries mainly relate to consumer behavior as well as to a lack of coordination between different actors in the supply chain... Food can be wasted due to quality standards, which reject food items not perfect in shape or appearance" (Gustavsson et al. 2011, v). This provides the basis for the notion of "imperfection" in this paper, that is, food that is imperfect in terms of its "size, shape, or color" (Gunders 2012, 18). The Natural Resources Defense Council, an organization headquartered in the United States that works to safeguard environmental resources while acknowledging a variety of reasons for the high percentage of wasted food, cites retailers as the driving force behind this food waste epidemic, finding that the influence of food retailers across the supply chain contributes to food waste from production to sale (Gunders 2012). Thus, this paper largely focuses on retail food purchasing locations and retailers' perspectives on consumer food preferences within the case study area of Fredericksburg, Virginia, USA.

Food production and food waste remain highly intertwined, with industrialized countries wasting far more than countries where a traditional agricultural model is practiced (Gustavsson et al. 2011). Over-consumption, too, is driving food waste in industrialized countries, and thus there is some concern that even if consumers were to change purchasing habits and buy imperfect foods with regularity, they might still buy too much and ultimately waste it (Turner 2014). Still, retailers play a key role in the issue of over-consumption as well and have an opportunity to reduce food waste at the consumer level by "reducing pack sizes, considering the impact of in-store promotions (e.g. BOGOF), clarifying date labelling" and so on (Bond et al. 2013). More broadly, our transition to industrial agriculture has changed the way we look at food, from a "source of nutrition and pleasure painstakingly 
produced by a combination of factors, both human and non-human" (Turner 2014) to a disposable commodity valued only in terms of its appearance and cost.

Moreover, despite the increase in food production that accompanied the transition to industrial agriculture, food insecurity continues to be a significant issue worldwide. From 2015 to 2016, the number of chronically undernourished people increased from 777 million to 815 million. Lipinski and colleagues (2013) estimate that if the current rate of food loss and food waste were cut in half, it would provide almost one-quarter of the gap between the food available today and the food needed in 2050. Further, perceptions of food quality, food waste, and food security are intertwined. The reduction of food waste is a critical way to enhance food security, and in developed countries, "consumers have become accustomed to purchasing foods of the highest cosmetic standards"; as a result, retailers often simply discard food that they do not perceive to be in line with consumer demands (Godfray et al. 2010, 816). Lipinski and colleagues $(2013,2)$ similarly found that food is wasted during production or harvest as a result of foods not meeting quality standards and edible food again is subject to loss at the distribution and marketing stage "because it is non-compliant with aesthetic quality standards". Thus, it would seem that the desire for perfect foods has contributed not only to an ecological crisis of waste management but also to global food insecurity.

\section{Investigating consumer perspectives on fresh produce}

To begin to understand how consumer perceptions of fresh produce are spatially mediated, and how these perceptions are understood and shaped by retailers, the author alongside a team of undergraduate researchers conducted interviews at a number of locations in the Fredericksburg, Virginia, USA area. Other large retailers which operate in the area and have expanded into organic offerings in recent years declined our request for an interview. The field study locations included: the Fredericksburg Farmers Market, the Spotsylvania County Farmers Market, the Fredericksburg Area Community Supported Agriculture (CSA) Project, and Wegmans, a regional grocery store chain. In total, we conducted 13 in-person interviews with a variety of participants including farmers, produce stand vendors, and supervisors. The four fieldwork locations differed in terms of their physical location and layout but represented some of the most accessible ways for local consumers to participate in an alternative food system and/or purchase locally grown or organic products.

Fredericksburg, Virginia has a population of 28,987 (U.S. Census Bureau 2016a) but is part of the larger Washington metropolitan area and, as such, contains a high number of residents who commute to the Washington, DC metropolitan area for work. Neighboring Fredericksburg to the south is Spotsylvania County, with a population of 132,010 (U.S. Census Bureau 2016b) and a similarly high percentage of commuters as it is also located in the larger Washington metropolitan area. The Spotsylvania County Farmers Market, in fact, occupies a large commuter lot, an interesting intersection between the realities of modern suburban life and the desire for locally grown products. This farmers' market is the largest in the region with over 60 vendors selling produce, dairy products, meats, baked goods, and other locally-produced items (The Farmers Market Co. 2017a). The Fredericksburg City farmers' market is smaller, with around 28 vendors, but is also the original farmers' market location, occupying a park in the historic downtown area for the past several decades (The Farmers Market Co. 2017b). Low-income consumers who shop at each location are eligible for up to \$20 USD in matching funds if they use the Supplemental Nutrition Assistance Program (SNAP), a program funded by the US Department of Agriculture, enabling local residents to purchase more affordable, and locally grown, produce (The Farmers Market Co. 2017c).

The Fredericksburg Area CSA Project has been in operation since 1997 (Fredericksburg Area CSA Project 2017a). Their organization, following the CSA model, connects consumers to a cooperative of local farms across the region (Fredericksburg Area CSA Project 2017a). Members of the CSA become shareholders in these farms, purchasing a share of the harvest that is distributed each week during the 20-week growing season at a park located in downtown Fredericksburg (Fredericksburg Area CSA Project 2017b). All of the products distributed through the CSA must be organic or certified naturally grown Fredericksburg Area CSA Project 2017c). In contrast to some CSAs where members receive a 
prefilled bag of produce, the Fredericksburg CSA utilizes a "Harvest Bar" approach, where members are able to fill their own bags with products, choosing amongst the week's allocated produce.

Wegmans is a supermarket chain headquartered in Rochester, New York that operates 92 stores across the mid-Atlantic and northern United States (Wegmans Food Markets 2017a). Though Wegmans is perhaps more in line with the mass retailer model of many modern grocery stores, it straddles the line between conventional and alternative food spaces. Wegmans operates its own organic farm and orchard in Canandaigua, New York, for example (Wegmans Food Markets 2017b). Wegmans stores also offer a variety of organic food options and partners with a network of over 400 family farms, providing customers an opportunity to purchase locally and regionally grown food, denoted by the "From Family Farms Near Our Stores" label (Wegmans Food Markets 2017b).

At each of these locations, our team conducted in-depth interviews to learn more about produce marketing, food waste, and consumer perceptions. A variety of sampling methods were utilized including cluster and voluntary sampling, though at the farmers' markets and CSA, snowball sampling was most commonly used. The farmers' market manager, for example, might suggest an organic farmer to interview who in turn suggests a local vendor. At Wegmans, the assistant store manager, who had extensive knowledge of produce, was interviewed. As mentioned, this research was completed with collaboration from four undergraduate researchers, and thus had more stringent time limitations than research that might be completed with the assistance of graduate students. However, at each of the farmers market and CSA locations, we continued to conduct interviews until we all agreed we had reached a sufficient level of saturation with our interview results. While it might have been helpful to interview additional Wegmans employees, the Assistant Store Manager was the only one to grant us a request for an interview and had been a former produce manager, so we found his interview provided us with a rich set of data.

Each interview was semi-structured, consisting of open-ended questions regarding the history and background of the vendor or location, impressions and perceptions of consumers, display techniques, and food waste. For example, we asked participants: "What are some typical questions you receive from customers about the appearance of an odd looking item?" and "What do you do with the produce you don't bring to the market?" In-depth interviewing has consistently been utilized by geographic researchers to understand the role of geography in shaping personal experience (Pennartz 1999; Holloway 2003; English et al. 2008) and for this paper, in-depth interviews offered a way to better understand consumer behavior, and produce sellers' perceptions of this behavior, in a variety of geographic settings. As a team, we developed an interview guide which provided a starting point for asking questions but the actual questions asked varied by location and were largely emergent based on the participant's responses. Each interview was audio taped, with permission, and then transcribed. Once each interview was transcribed, they were coded and analyzed using Nvivo 10, a qualitative analysis software package.

Even after conducting a small number of interviews, several key themes were clearly apparent. First, at all of the case study locations, it was evident that participants, which included vendors as well as farmers, were aware of consumer preferences and had experienced consumers rejecting produce perceived to be imperfect or the last of an item. Secondly, there was a consistent emphasis on signage and displays as a way to build relationships with consumers, convey information or correct misinformation, and generally shape the shopping experience. Our sense of place is influenced by these locational cues and symbolic imagery and a supermarket might seek to recreate a farmers' market experience using elements found in more alternative food systems. Finally, although the study locations differed significantly in terms of their marketing strategies, food waste practices, and overall geography, the industrial food system has significantly impacted the expectations of consumers with shoppers demanding a standard of perfection not often found on a family farm.

\section{Searching for perfection}

Across all of our study locations, it was clear that farmers' market vendors and other produce sellers were keenly aware of consumer preferences and sought to create an atmosphere that would be appealing to buyers. The display strategies utilized, and the desire to create the look of a bountiful 


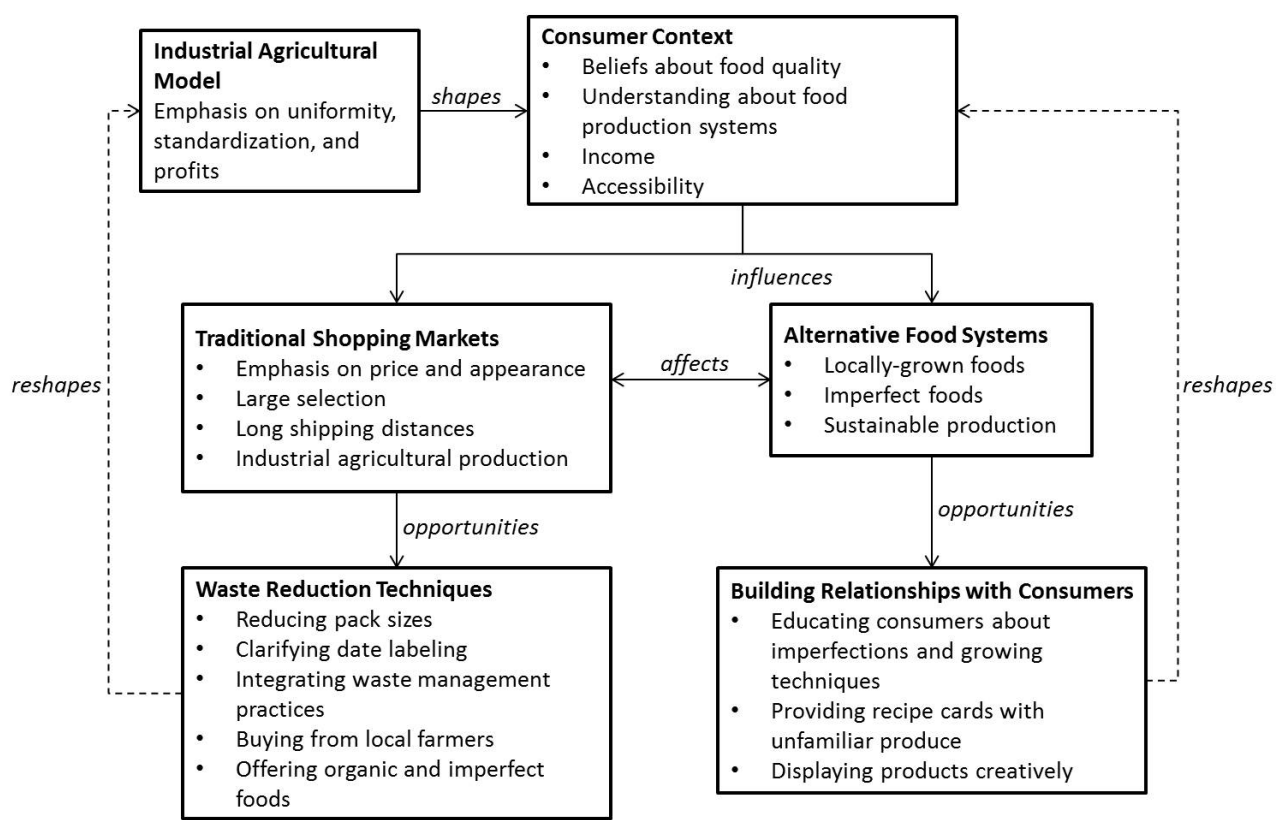

Figure 1. Conceptual model of consumer perceptions of fresh produce quality and retail practices in Fredericksburg, Virginia, USA. Figure by author.

harvest, contributes to wasted food, but as these interviews demonstrate, how this waste is handled differs across food purchasing locations. Additionally, an analysis of the interview findings reveals that even within alternative food systems, consumers bring with them an expectation of the same level of perfection found in traditional supermarkets, though these expectations can be reshaped as consumers form relationships with producers (Fig. 1).

\section{Displaying a bounty of food}

Food displays can have a direct impact on consumer purchasing behavior (California Department of Public Health 2011; Meadowcroft \& Bernard 2016), and not surprisingly, factor into decision-making at both alterative and traditional food purchasing locations. For imperfect foods in particular, farmers' market vendors discussed various display and packaging strategies. An extremely large or misshapen squash might be placed at the end of the table as a way to draw customers into a booth and start a conversation, as Frank, ${ }^{1}$ the manager of the Spotsylvania County Farmers Market, explained: "[Vendors] will find different ways of marketing [imperfect food]. Some of them, if they have a really unusual one, they might use it as a display item to talk about" (Frank, Spotsylvania County Farmers Market, 2016 Interview). If a customer seemed reluctant to buy a particular fruit or vegetable based on its appearance, a vendor might approach the customer and try and explain the peculiarity, as Tom explained:

When we're getting watermelon you see wheFre its sat on a rock or where it's been on the ground, and as long as it's good, people will buy it, but some people are like, "Oh that's weird..." A bunch of people ask why it's deformed. It's sitting on the ground. And it has the yellow spots, and that part's just on the ground where it doesn't get any sunlight. (Tom, Spotsylvania County Farmers Market, 2016 Interview)

In this way, farmers and produce vendors can alter consumer perception by creating a dialogue about why imperfections exist. If consumers understand why foods look the way they do, and understand what to expect when selecting particular foods, they might be less likely to reject a product based on imperfections alone. 
That said, participants continually commented that consumers search for the "best" piece of produce, often digging through a bin to compare items and find the "perfect" one. Tom mentioned:

A lot of people actually dig around... They're just looking for the perfect one, but usually there's not really a perfect one because every single one is mostly the same. Usually they grab one and they let that one down and they grab another one and then they go and choose the one they picked up first. (Tom, Spotsylvania County Farmers Market, 2016 Interview)

Interestingly, this rummaging around can actually damage produce, though consumers are often unaware of the effects of their behavior. Steve, an Assistant Store Manager at the Fredericksburg Wegmans, explained:

If I go up to this display of apples, as I'm going through it [I would] be aware that as I'm moving things around, if I'm not careful I will damage that product and then unfortunately the person that comes along behind me may have a damaged product because I wasn't handling it correctly. (Steve, Assistant Store Manager, Wegmans, 2016 Interview)

This presents a challenge for retailers since products might be unblemished when they are initially set out for display but become damaged by consumers handling them too roughly. Most research regarding bruising in produce is focused on damage at harvest or packing (Brown et al. 1993; Opara \& Pathare 2014), but additional research is needed to determine the role consumers play in contributing to produce damage at the point of sale.

Consumers are generally unwilling to buy the last of an item (Meadowcroft \& Bernard 2016). Steve, the Wegmans Assistant Store Manager, said simply, "No one's going to buy the last one. Why would you want to?" (2016 Interview). Ed had a similar sentiment, noting:

I think people think that when there's only one of something left on a shelf or a table that there's something inherently wrong with it. Rather than the idea that, well, there's only one left they must have been selling like crazy. That's something that's coming from back in the caveman part of your brain, way back there from a thousand generations ago in some way or another. The last thing on the table is always the hardest thing to sell. (Ed, Spotsylvania County Farmers Market, 2016 Interview)

One way to avoid this problem is to continually restock, as Jeff commented: "You never see the last one in the bin usually because they keep restocking it" (Fredericksburg Farmers Market, 2016 Interview). This continual restocking entails waste, however. As the Natural Resources Defense Council found, "Most retail stores operate under the assumption that customers buy more from brimming, fully stocked displays, preferring to choose their apples from a towering pile rather than from a scantly filled bin" (Gunders 2012). In order to keep the perception of a large supply to appease consumers, vendors at farmers markets even late in the day often keep a significant supply of food on display. At all of our case study locations, there was a trend in portraying a bounty of food, whether spilling out of large crates or piled high on tables. Dan noted:

Customers want to see a bounty. If it's just like two things on a table, it just doesn't look appealing. I think it's like instinct... If you let it dwindle down, nobody will come to it. (Fredericksburg Farmers Market, 2016 Interview )

At supermarkets, too, the bounty of food on display is impressive. Steve explained, "We try to merchandise [food] so it's appealing and if you walk in and you see a huge display of something we want it to make you stop and go, 'Hmm, wow, apparently I need to have this"' (Wegmans, 2016 Interview). The difficulty with maintaining such a large quantity, however, is that if you never allow yourself to be low on food, you have to constantly keep your inventory high even when the number of buyers is low. Furthermore, if consumers are attracted to displays that have these large quantities of products (Fig. 2), vendors who have smaller quantities might be less attractive to consumers, even if they also have less food waste. Research on food retailers supports this notion, with survey data finding that satisfaction with the produce section significantly influences consumer shopping practices, and further that consumer perceptions of the quality and freshness of produce are the largest drivers of this satisfaction (Beswick et al. 2014). Moreover, food losses and the desire to maintain ample stock of fresh produce are closely linked, and "together represent the most under-managed lever in the grocery business" (Beswick et al. 2014, 2). Tackling these issues at the retail level could significantly reduce food waste as well as increase profits (Beswick et al. 2014). 


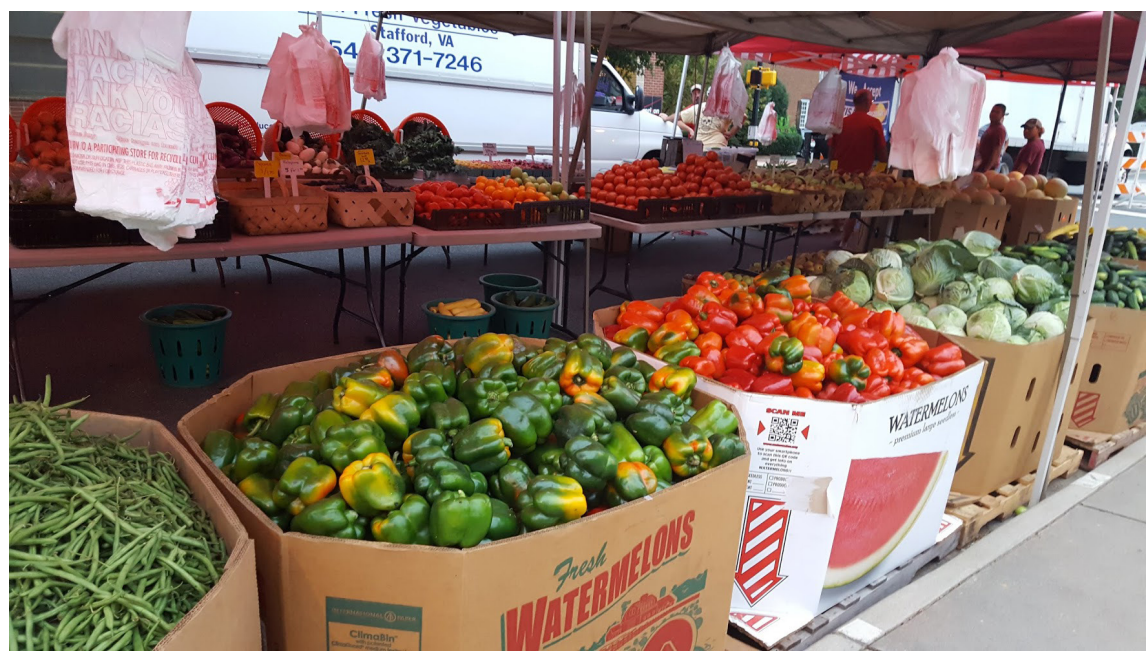

Figure 2. Large bins of produce at the Fredericksburg, Virginia Farmers Market, 2016. Photo by author.

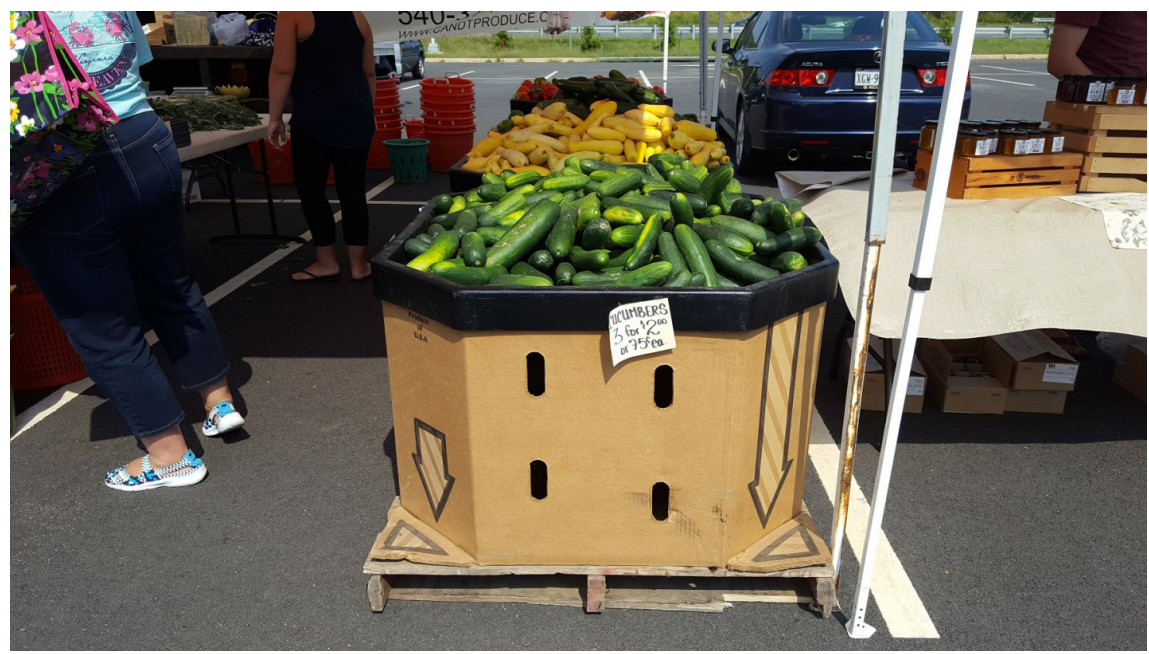

Figure 3. Strategy for displaying produce at the Spotsylvania County Farmers Market, 2016. Photo by author.

There are some strategies for dealing with this issue, however. One is to display products in a way that makes them appear to have a large quantity. At the Spotsylvania County Farmers Market, for example, we found similar cardboard produce boxes that had been full of products at other locations used with a plastic cap that made the box appear to be overflowing with produce when in fact the box itself was empty (Fig. 3). At the Fredericksburg Farmers Market, we found a vendor selling "salsa kits," small produce baskets with a variety of tomatoes, peppers, and onions. Rather than discard the last few peppers or onions, or restock, they could be reconfigured in a way that would be appealing to consumers. Even at the Fredericksburg Area CSA Project, there was an emphasis on the importance of giving consumers choices. Typically at CSAs, members receive a basket or bag of produce each week that has been preselected with the member's allotted weekly share of the harvest. A bag might contain a head of lettuce, a bunch of tomatoes, several squash, and so on. Within the pastyear, the Fredericksburg Area CSA Project shifted to a what they term a "Harvest Bar" approach, as Karen, one of the organizers of the CSA explained: 
It used to be back in the beginning it used to be everything was on display and it said pick two, pick one whatever, then we morphed into bagging everything for everybody and we had a chalkboard and it said this is what's in your bag in fact the email would go out and say what's in the bag. It was last year we went back to the what we call the... harvest bar, so everyone can see what there is and it says pick one, pick two or whatever. (Karen, Fredericksburg CSA, 2016 Interview)

Mary, another organizer, noted that the reason for the change was because "the perception of choice seems to be attractive to consumers" (Fredericksburg CSA, 2016 Interview). It would seem, even within alternative food systems, there is the desire to be discriminating about our produce selections and to be given the opportunity to find our "perfect" item. This fits in with previous research on consumer preferences and food waste that found that consumers shop at retailers with an expectation of cosmetic perfection (Gunders 2012). Thus, according to our discussions with the CSA,the ability to choose the "best" among the various options is important for consumers. This shift in how produce is displayed and presented to consumers likely has little effect on how much food is wasted at the distribution point, since in a CSA, produce is allocated to each member based on the harvested amount, but could potentially reduce food waste within a household. Indeed, research by Cooley and Lass (1998) on CSA members in the Amherst-Massachusetts, USA region found that while members were generally satisfied, one-quarter felt that too much produce was provided, which contributed to waste. The "Harvest Bar" model could potentially address this concern. Further, Stefan and others (2013) found that consumers' meal planning and shopping routines were important predictors of food waste, and thus adjusting the CSA distribution in a way that provided consumers choice as well as offered suggestions, as the Fredericksburg CSA does in the form of recipe suggestions for ingredients, could significantly reduce the household waste of members.

Displays and signage were mentioned at the various case study locations as a critical way to build a relationship with consumers. At Wegmans, for example, signage included information about local farms and the seasonality of various foods. At the Spotsylvania Farmers Market, a particularly creative sign stated "Worm Alert!" and informed consumers that worms might be present in the ears of corn and offered instructions for how to trim the ears (Fig. 4). Lisa, a worker at that stand, explained their strategies:

The corn has bugs in it only at the very, very top and people don't realize that so they're throwing away a perfectly good ear of corn when it's only at the top... That's why I have to make signs like that and I have to try to educate people so that they know that they're ending their corn season early for no reason. (Lisa, Spotsylvania County Farmers Market, 2016 Interview)

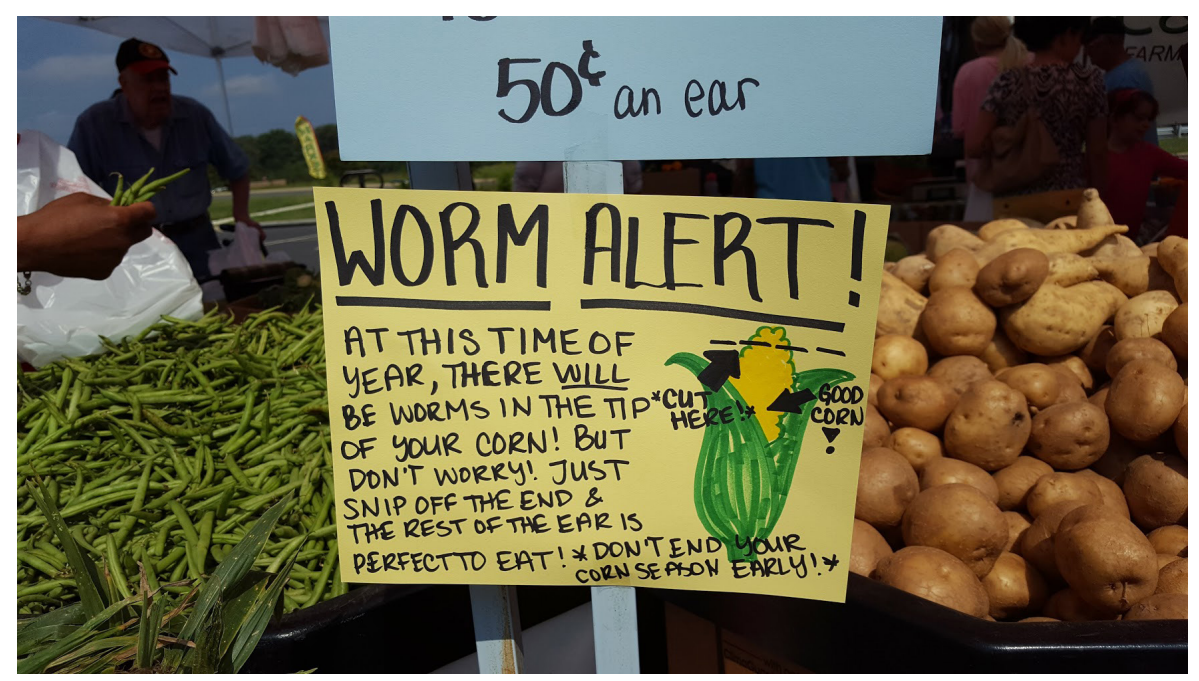

Figure 4. Sign informing customers of worms in ears of corn at the Spotsylvania County Farmers Market, 2016. Photo by author. 
The same vendor also included recipe cards when unfamiliar produce was offered for sale. Lisa continued:

Sometimes I put out recipes for people to take pictures of, sometimes I will walk around. We usually have someone who's restocking and usually they say, "Well, that's really good if you do this with it" or "I've had that before and it's like this." I'm the same way, picky wise, so I try to tell people in that way. I try to ask what they're looking for and at least point them in the right direction. (Lisa, Spotsylvania County Farmers Market, 2016 Interview)

It is this relationship with the growers and suppliers of our foods that set farmers' markets and other alternative food systems apart from large retailers and might help enable these locations to sell foods that might otherwise be rejected by consumers. As Jeff at the Fredericksburg Farmers Market explained:

You go down to [the local supermarket] and ask the guy filling the shelves... where it grew, how it grew, why did you grow this particular variety - here you get those answers, there you can't. Most of those guys don't know where it comes from. So, you know, it's a little more buyer seller relationship. I mean, you create a relationship with the guy who's selling to you. (Jeff, Fredericksburg Farmers Market, 2016 Interview)

This relationship can thus help reconnect consumers with producers, and educate consumers on the intricacies involved in growing food sustainably. Further, if the survey findings from Beswick and colleagues (2014) are correct, and consumers indeed value quality and freshness above all else, alternative food spaces like farmers markets are well-positioned to explain to consumers what to look for in terms of quality. Lisa, for example, explained how consumers often think that produce that is perfect looking is best, and how she works with them to change their perception.

I'll walk up to them and I'll try to talk them through it and be like "Well, you don't really want it to be perfect because a perfect cantaloupe is never good..." Usually the ugliest ones are the best... And then you want it to be soft, and people don't want a soft one they want a firm one, but really those ones are going to be the ones that are unripe. So, a lot of people don't know a lot about that either. (Lisa, Spotsylvania County Farmers Market, 2016 Interview).

Overall, our interview findings confirmed that, indeed, consumers place a high importance on quality and freshness but that they often mistakenly believe that a perfect appearance is indicative of quality, when that is often not the case.

As farmers' markets and alternative food systems have grown, mass retailers have increasingly adopted techniques that recreate the farmers' market experience. Even at big-box stores, signs advertising local foods can be found scattered around the produce section, though these signs might not actually contain any specific information about local farms. At Wegmans, signs in the front of the store highlight the location of which local farms produced various foods and display placards often have the photograph and story of the farm owners (Fig. 5). These retailers might also utilize crates and rustic-looking displays, again to attempt to recreate the experience of shopping in a farmers' market.

\section{Handling food waste}

That said, while supermarkets have sought to become increasingly like farmers' markets, and farmers' markets are subject to the same consumer preferences as supermarkets, these locations vary considerably in terms of their treatment of food waste. Not surprisingly, foods that are not sold at farmers' markets stay within a closed system, returning to a compost pile to be reused into soil. When describing what happens to food that is not sold at the market, Ed explained:

My family eats a lot of it, and I give some of it away, and some of it eventually finds its way into the compost pile. It really depends on which individual product it is. I personally don't really like okra a whole lot so I'm probably not going to eat that okra (Spotsylvania County Farmers Market, 2016 Interview).

Dan noted a similar treatment of unsold food, saying, "We put it in the composter or we eat it" (Fredericksburg Farmers Market, 2016 Interview). The Fredericksburg Area CSA has a scholarship program and donates unclaimed food to their scholarship family. Other farmers' market vendors 


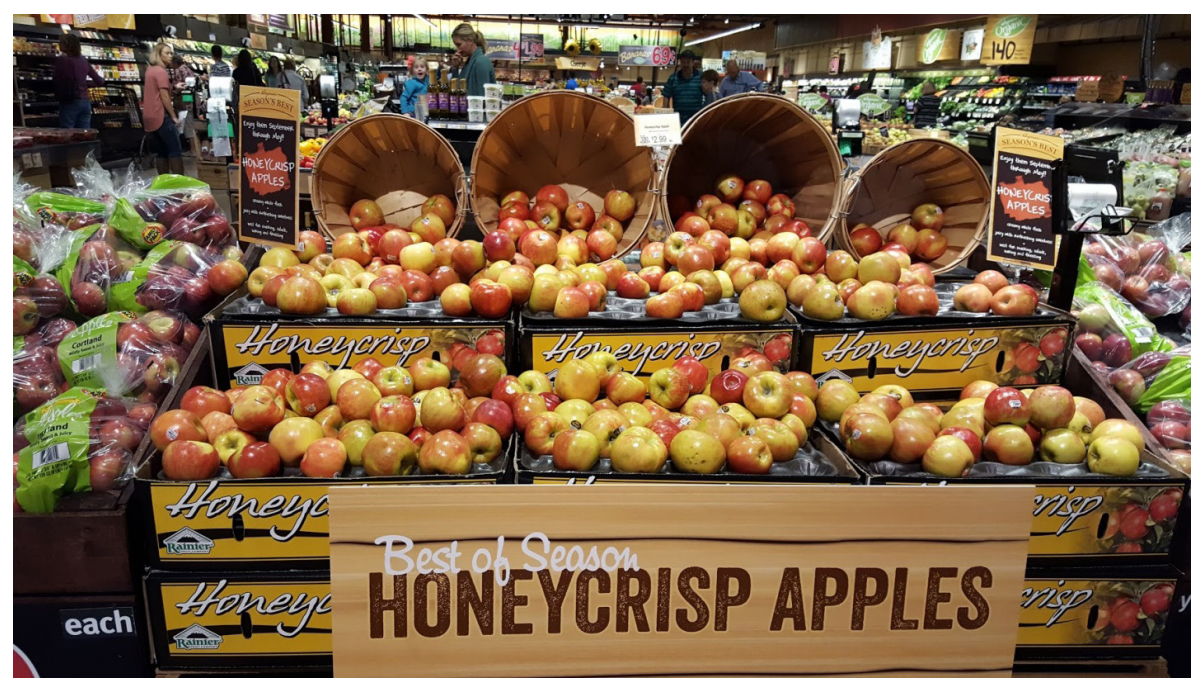

Figure 5. Seasonal display at the Fredericksburg, Virginia Wegmans, 2016. Photo by author.

similarly donate unsold food at the end of the market day. The practice of composting otherwise "wasted" food stands in stark contrast to food losses at traditional retailers and in home kitchens, where food is typically thrown out and sent to a landfill. In fact, the United States Department of Agriculture estimates that more food reaches landfills and incinerators than any other single material and comprises around one-fifth of municipal solid waste (Buzby et al. 2014). In 2014, only 5\% of food waste was diverted from landfills or incinerators for composting (Buzby et al. 2014). More broadly, the transition to industrial agriculture points not just to a changing way we handle food waste, but also, as previously mentioned, to a shift in how we view food (Turner 2014; Campbell et al. 2017 ), from something that inherently has value and nutrients and can be composted to something that is discarded and simply "thrown away."

Wegmans has increased its attention on wasted food in recent years with Steve, the Assistant Store Manager, noting, "We try to throw nothing away; our goal is zero" (Wegmans, 2016 Interview). Produce that does not sell or is too blemished to sell is used in the cut produce section, where customers can buy cleaned and cut produce ready for use in recipes. If produce is too damaged to be used in that section, it is used in the prepared food section. Tomatoes, for example, might be used to make a sauce. At some Wegmans stores in Pennsylvania, a local farm picks up discarded food and makes compost out of it which is then bagged and sold in stores, creating, as Steve describes, "a complete closed circle from tree to store to composter and then back to the earth" (Wegmans, 2016 Interview).

While our food system has changed in recent decades, with the growth of farmers' markets, locally grown, and organic products, the desire for perfection remains steadfast. At more traditional retail locations, perfection has become the standard. Steve explained:

If the majority of our produce looked less than what we wanted it to, then that's what you would come to accept. We don't want that to be the rule, we want it to never happen. So our standards and our expectations are that you should be able to buy a perfect piece of fruit. It's as simple as that. (Steve, Assistant Store Manager, Wegmans, 2016 Interview).

For Wegmans consumers, this makes the shopping experience quite simple; the quality controls are such that any apple you pick up will be a perfect apple.

\section{Perfection as the standard}

However, as we have transitioned to an industrialized agricultural system, we have also transitioned away from imperfection. Industrializing food and mass producing even our fruits and vegetables 
creates a standard of uniformity and has led to exacting specifications demanded by international trade regulations and retailers (Halloran et al. 2014; Gobel, et al. 2015; de Hooge et al. 2017). To fit through mechanized processors, produce must be of a standard size and shape, and further the mass application of chemical pesticides and fertilizers enables us to minimize blemishes that might appear with a less regimented growing process. Adam summed it up succinctly, "It's hard to grow something perfect... Most all of it does have blemishes here or there" (Fredericksburg Farmers Market, 2016 Interview). Lisa noted similarly:

A lot of people will look at it and if it's not perfect they'll put it back and try to find the perfect tomato, but it's really hard to do that when you actually come to a real farm because it's coming from a field, there are animals, there are bugs, there's going to be scars on it from where it grew, so it's going to be very hard for people who really want a perfect tomato. (Lisa, Spotsylvania County Farmers Market, 2016 Interview)

We have become so disconnected from how our food is grown that, quite simply, we have forgotten how difficult it is to grow food. A gardener who planted tomatoes from seeds, pruning and watering them throughout the growing season, would hardly discard a tomato if it was unevenly colored or a little misshapen. If a tomato had a slightly rotten area, the area would likely be discarded rather than the entire tomato. For modern consumers, however, the supermarket and its mass produced harvest has become the standard and perfection is often expected even in alternative food venues. Food waste in the United States in particular results from "unrealistic and unyielding cosmetic standards, according to official data and interviews with dozens of farmers, packers, truckers, researchers, campaigners and government officials" in what can be described as a "cult of perfection" that is continually linked to the significant amount of wasted food (Goldenberg 2016). Frank, the manager of the Spotsylvania County Farmers Market, explained that consumers are only slightly less discriminating at farmers' markets:

I don't think it's as dramatic as one might think. There's a segment of folks who come here who understand that when you grow vegetables, some of them are going to be blemished, some of them are going to come out looking strange and they're willing to accept that, but there are a lot of folks who are looking for fresh produce [and] their only experience is at the grocery store. They want something that's fresher but their only experience is with perfect produce, so they may lean a little bit, but they're not crunchy granola folks. (Frank, Spotsylvania County Farmers Market, 2016 Interview)

Thus, the average farmers' market shopper is not necessarily willing to accept imperfection in exchange for locally grown. At the CSA, too, consumers have come to expect a standard that is only found in large supermarkets. Mary noted:

It seems like they expect food that you're getting from the local farmers that's a different variety than the grocery store to withstand the same handling or [have the same] the longevity. I kind of almost wish they would understand that that's why those beautiful heirloom tomatoes aren't in the grocery store because they will split quickly and you need to eat them fresh... it's not something that's going to sit on your counter for two weeks. (Mary, Fredericksburg CSA, 2016 Interview)

This desire for perfection is thus biased toward industrial agriculture because only an industrial system can approach a uniform, "perfect" standard, while at the same time, it sets an expectation that more traditional forms of farming cannot meet. For Dan, the standard of perfection that is found in modern supermarkets is unappealing:

In stores, everything looks weird and polished. At farmers' markets, there are things that are kind of imperfect, but I think prettier. Like a tomato: I like tomatoes that have just the right amount of imperfections, like it looks real and doesn't look like a Christmas ornament. (Fredericksburg Farmers Market, 2016 Interview)

Dan offers a reminder that perfect is not natural. In the natural world, imperfections abound. Even in other arenas, however, modern society has created a standard of perfection that is unattainable. Consider magazines, for example, and the photo-retouched celebrities that adorn their glossy covers. This standard of beauty is not just unrealistic, it is simply unachievable, but it is a standard that will only be perpetuated as the industrial food system continues its dominance. 


\section{Conclusions}

Just as alternative food systems seek to reconnect consumers to the growers of their food, a burgeoning body of research in geography has sought to similarly reconnect the previously isolated concepts of food, farmers, and nature (Winter 2003). This paper has sought to refocus attention to the geography of food at the local level, specifically examining how consumer food preferences are perceived by local retailers in Fredericksburg, Virginia, USA and how these locations serve as spaces of transition and reconnection. While perceptions of consumer food preferences are just that, interpretations of how people see and understand food, they can shed light on how consumers and retailers alike serve to make and remake our agricultural ideals (Godfray et al. 2010; Lipinski et al. 2013). Furthermore, reconnecting consumers and producers in this way helps uncover how retailers market, display, and ultimately waste produce (Goldenberg 2016).

As global food systems have transitioned to an industrial agricultural model, there has been a corresponding shift in consumer food preferences (Regmi 2001). Even as we are starting to transition away from a highly mechanized, mass production model, the preferences that have developed over the last few decades have remained. This research has demonstrated that even in alternative food buying locations, consumers often bring with them the same expectations for perfection that they would have at a supermarket. There is the possibility, however, that these preferences can be reshaped, but this transition will likely take some time as we have become highly enmeshed in the industrial agricultural model. As consumers build relationships with the people who grow their food, particularly at places like farmers' markets, this relationship will foster a greater awareness of how food is grown.

In talking with farmers and produce vendors, it was clear that there is a desire among consumers to know more and that when they know more, they are receptive to change. Even at Wegmans, for example, learning that it is often the consumer who is responsible for bruising produce and not the supplier could lead to a shopper being a bit more cautious when digging through a bin of apples. At a local farmers' market, learning more about the growing process and the intricacies of organic versus conventional farming methods could lead to skepticism of the industrial organic model and a desire for a nuanced understanding of what it means to sustainably grow food. This reconnection to the local could once again privilege local geography over standardization, and sustainability over perfection. This paper seeks to contribute to the growing body of literature on the reconnection of food and nature discussed in Winter (2003) from an explicitly geographical perspective, turning our attention to spaces of reconnection at the local level and the building of relationships between consumers and producers. It is this relationship that is often missing in the modern agricultural system and for consumers and sellers alike, the opportunity to build a relationship and become educated about foods and food production seems to be a critical component of the appeal of an alternative model. Undoubtedly, as we learn more about how our food is produced, and how much of it is ultimately wasted, we can start to make small changes that will have a tremendous impact on the larger system.

\section{Notes}

${ }^{1}$ Names have been changed to protect privacy.

\section{Acknowledgements}

I would like to thank the chief editor of Fennia and Christoph Rupprecht for their support as well as the comments from the anonymous reviewers whose suggestions significantly improved the quality of this work. My thanks also goes to our interview subjects at the Fredericksburg Farmer's Market, Spotsylvania County Farmer's Market, Fredericksburg CSA, and Wegmans whose generosity with their time was invaluable. Finally, my immense thanks goes to my undergraduate research students: Meredith Gregory, Clara Ludkte, Christian Meoli, and Michael Ryan. Their dedication, professionalism, and excitement about this project was deeply appreciated. This project was generously supported by a Jepson Fellowship at the University of Mary Washington. 


\section{References}

Alkon, A. H. \& McCullen, C. G. (2011) Whiteness and farmers markets: performances, perpetuations ... contestations? Antipode 43(4) 937-959. https://doi.org/10.1111/j.1467-8330.2010.00818.x

Bacos, J., Beswick, P., Demure, B., Harrison, N., Siemssen, S. \& Trentini, R. (2014) A Retailer's Recipe for Fresher Food and Far Less Shrink. Oliver Wyman, Boston. <http://www.oliverwyman.com/content/ dam/oliver-wyman/g/obal/en/2014/jul/2014 OW aRetailersRecipe 4.pdf> 12.1.2018.

Barker, D. (2007) The Rise and Predictable Fall of Globalized Industrial Agriculture. The International Forum on Globalization. <http://ifg.org/v2/wp-content/uploads/2014/05/ag-report.pdf> 11.7.2017.

Bell, D. \& Valentine, G. (eds.) (1997) Consuming Geographies: We Are Where We Eat. Routledge, New York.

Bond, M., Meacham, T., Bhunnoo, R. \& Benton, T. G. (2013) Food waste within global food Systems. Global Food Security Programme. <https://www.foodsecurity.ac.uk/publications/food-waste-withinglobal-food-systems.pdf> 12.1.2018.

Brown, A. (2001) Counting farmers markets. Geographical Review 91(4) 655-674. https://doi. org/10.1111/j.1931-0846.2001.tb00246.x

Brown, G. K., Schulte, N. L., Timm, E. J., Armstrong, P. R. \& Marshall, D. E. (1993) Reduce apple bruise damage. Tree Fruit Postharvest Journal 4(3) 6-10. <http://postharvest.tfrec.wsu.edu/pages/J4/3A> 18.1.2018.

Buzby, J. C., Wells, H. F. \& Hyman, J. (2014) The estimated amount, value, and calories of postharvest food losses at the retail and consumer levels in the United States. Economic Information Bulletin 121. https://doi.org/10.2139/ssrn.2501659

California Department of Public Health (2011) Retail Fruit \& Vegetable Marketing Guide. Network for a Healthy California. <http://ucce.ucdavis.edu/files/datastore/234-2083.pdf> 12.7.2018.

Calvo-Porral, C., Medín, A. F. \& Losada-López, C. (2017) Can marketing help in tackling food waste?: Proposals in developed countries. Journal of Food Products Marketing 23(1) 42-60. https://doi.org /10.1080/10454446.2017.1244792

Campbell, H., Evans, D. \& Murcott, A. (2017) Measurability, austerity and edibility: introducing waste into food regime theory. Journal of Rural Studies 51 168-177. https://doi.org/10.1016/j. jrurstud.2017.01.017

Cooley, J. P. \& Lass, D. A. (1998) Consumer benefits from community supported agriculture membership. Review of Agricultural Economics 20(1) 227-237. https://doi.org/10.2307/1349547

de Hooge, I. E., Oostindjer, M., Aschemann-Witzel, J., Normann, A., Loose, S. M. \& Almli, V. L. (2017) This apple is too ugly for me!: Consumer preferences for suboptimal food products in the supermarket and at home. Food Quality and Preference 56(part A) 80-92. https://doi.org/10.1016/j. foodqual.2016.09.012

Edwards, F. \& Mercer, D. (2012) Food waste in Australia: the freegan response. The Sociological Review 60(S2) 174-191. https://doi.org/10.1111/1467-954X.12044

English, J., Wilson, K. \& Keller-Olaman, S. (2008) Health, healing and recovery: therapeutic landscapes and the everyday lives of breast cancer survivors. Social Science \& Medicine 67(1) 68-78. https:// doi.org/10.1016/j.socscimed.2008.03.043

Evans, D. (2012) Beyond the throwaway society: ordinary domestic practice and a sociological approach to household food waste. Sociology 46(1) 41-56. https://doi. org/10.1177/0038038511416150

Feagan, R. (2007) The place of food: mapping out the 'local' in local food systems. Progress in Human Geography 31(1) 23-42. https://doi.org/10.1177/0309132507073527

Feagan, R., Morris, D. \& Krug, K. (2004) Niagara region farmers' markets: local food systems and sustainability considerations. Local Environment 9(3) 235-254. https://doi. org/10.1080/1354983042000219351

Feenstra, G. W. (1997) Local food systems and sustainable communities. American Journal of Alternative Agriculture 12(1) 28-36. https://doi.org/10.1017/S0889189300007165

Feenstra, G. (2002) Creating space for sustainable food systems: lessons from the field. Agriculture and Human Values 19(2) 99-106. https://doi.org/10.1023/A:1016095421310

Fernandez-Cornejo, J. (2004) The Seed Industry in US Agriculture: An Exploration of Data and Information on Crop Seed Markets, Regulation, Industry Structure, and Research and Development (No. 33671). United States Department of Agriculture, Economic Research Service. <http://ageconsearch.umn. edu/record/33671> 10.7.2018.

Fredericksburg Area CSA Project (2017a) <http://www.fredericksburgcsa.com/> 
Fredericksburg Area CSA Project (2017b) Become a member! <http://www.fredericksburgcsa.com/ become-a-member/>

Fredericksburg Area CSA Project. (2017c) Our farmers. <http://www.fredericksburgcsa.com/about/ourfarmers/>

Gehlhar, M. \& Coyle, C. (2001) Global food consumption and impacts on trade patterns. In Regmi, A. (ed.) Changing Structure of Global Food Consumption and Trade. Market and Trade Economics Division, Economic Research Service, U.S. Department of Agriculture and Trade Report, WRS-011. <https://www.ers.usda.gov/publications/pub-details/?pubid=40319>10.7.2018.

Gobel, C., Langen, N., Blumenthal, A., Teitscheid, P. \& Ritter, G. (2015) Cutting food waste through cooperation along the food supply chain. Sustainability 7 1429-1445. https://doi.org/10.3390/ $\underline{\text { su7021429 }}$

Godfray, H. C.J., Beddington, J. R., Crute, I. R., Haddad, L., Lawrence, D., Muir, J. F., Pretty, J., Robinson, S., Thomas, S. M. \& Toulmin, C. (2010) Food security: the challenge of feeding 9 billion people. Science 327(5967) 812-818. https://doi.org/10.1126/science.1185383

Goldenberg, S. (2016) Half of all US food produce is thrown away, new research suggests. The Guardian 13.7.2016. <https://www.theguardian.com/environment/2016/jul/13/us-food-waste-ug/yfruit-vegetables-perfect> 11.1.2018.

Gunders, D. (2012) Wasted: how America is losing up to 40 percent of its food from farm to fork to landfill. Natural Resources Defense Council August 2012 IP:12-06-B. <https://www.nrdc.org/sites/ default/files/wasted-food-IP.pdf> 23.3.2017.

Gustavsson, J., Cederberg, C., Sonesson, U., van Otterdijk, R. \& Meybeck, A. (2011) Global Food Losses and Food Waste. Food and Agricultural Organization of the United Nations, Rome. <http://Www. fao.org/docrep/014/mb060e/mb060e00.pdf> 6.7.2017.

Guthman, J. (2008a) Bringing good food to others: investigating the subjects of alternative agrifood practices. Cultural Geographies 15(4) 425-441. https://doi.org/10.1177/1474474008094315

Guthman, J. (2008b) If they only knew: colorblindness and universalism in alternative agrifood institutions. The Professional Geographer 60(3) 387-397. https://doi. org/10.1080/00330120802013679

Hodges, R. J., Buzby, J. C. \& Bennett, B. (2011) Postharvest losses and waste in developed and less developed countries: opportunities to improve resource use. The Journal of Agricultural Science 149(S1) 37-45. https://doi.org/10.1017/S0021859610000936

Halloran, A., Clement, J., Kornum, N., Bucatariu, C. \& Magid, J. (2014) Addressing food waste reduction in Denmark. Food Policy 49(1) 294-301. https://doi.org/10.1016/j.foodpol.2014.09.005

Holloway, J. (2003) Make-believe: spiritual practice, embodiment, and sacred space. Environment and Planning A 35(11) 1961-1974. https://doi.org/10.1068/a3586

Horrigan, L., Lawrence, R. S. \& Walker, P. (2002) How sustainable agriculture can address the environmental and human health harms of industrial agriculture. Environmental Health Perspectives 110(5) 445-456. https://doi.org/10.1289/ehp.02110445

Jarosz, L. (2008) The city in the country: growing alternative food networks in Metropolitan areas. Journal of Rural Studies 24(3) 231-244. https://doi.org/10.1016/j.jrurstud.2007.10.002

Kneafsey, M., Cox, R., Holloway, L., Dowler, E., Venn, L. \& Tuomainen, H. (2008) Reconnecting Consumers, Producers and Food: Exploring Alternatives. Berg, New York. https://doi. org/10.5040/9781350047631

Kremer, P. \& DeLiberty, T. L. (2011) Local food practices and growing potential: mapping the case of Philadelphia. Applied Geography 31(4) 1252-1261. https://doi.org/10.1016/j.apgeog.2011.01.007

Lipinski, B., Hanson, C., Lomax, J., Kitinoja, L., Waite, R. \& Searchinger, T. (2013) Reducing food loss and waste. World Resources Institute Working Paper. <http://staging.unep.org/wed/2013/docs/ WRI-UNEP-Reducing-Food-Loss-and-Waste.pdf> 11.7.2017.

Mack, J. \& Tong, D. (2015) Characterizing the spatial and temporal patterns of farmers' market visits. Applied Geography 63(2015) 43-54. https://doi.org/10.1016/j.apgeog.2015.06.005

Meadowcroft, D. \& Bernard, J. C. (2016) Understanding the effect of product displays on consumer choice and food waste: a field experiment. Selected Papers of the 2016 Agricultural \& Applied Economics Association Annual Meeting, Boston, Massachusetts. <https://ageconsearch.umn.edu/ bitstream/235543/2/AAEA_2016_DEVONMEADOWCROFT.pdf> 12.7.2018.

Mooney, C. (2018) The staggering environmental footprint of all the food that we just throw in the trash. The Washington Post 4.18.2018. <https://www.washingtonpost.com/news/energyenvironment/wp/2018/04/18/americans-waste-about-a-quarter-of-the-food-they-buy-and-theenvironmental-consequences-are-staggering > 9.7.2018. 
Nixon, R. (2015) Food waste is becoming serious economic and environmental issue, report says. The New York Times 25.2.2015. <https://www.nytimes.com/2015/02/26/us/food-waste-is-becomingserious-economic-and-environmental-issue-report-says.htm/> 9.7.2018.

Opara, U. L. \& Pathare, P. B. (2014) Bruise damage measurement and analysis of fresh horticultural produce - a review. Postharvest Biology and Technology 91 9-24. https://doi.org/10.1016/j. postharvbio.2013.12.009

Pennartz, P. J. J. (1999) Home: the experience of atmosphere. In Cieraad, I. (ed.) At Home: An Anthropology of Domestic Space, 95-106. Syracuse University Press, Syracuse, NY.

Pollack, S. L. (2001) Consumer demand for fruit and vegetables: the U.S. example. In Regmi, A. (ed.) Changing Structure of Global Food Consumption and Trade. Market and Trade Economics Division, Economic Research Service, U.S. Department of Agriculture and Trade Report, WRS-01-1. <https:// www.ers.usda.gov/publications/pub-details/?pubid=40319> 10.7.2018.

Regmi, A. (2001) Changing structure of global food consumption and trade: an introduction. In Regmi, A. (ed.) Changing Structure of Global Food Consumption and Trade. Market and Trade Economics Division, Economic Research Service, U.S. Department of Agriculture and Trade Report, WRS-01-1. <https://www.ers.usda.gov/publications/pub-details/?pubid=40319> 10.7.2018.

Regmi, A. \& Dyck, J. (2001) Effects of urbanization on global food demand. In Regmi, A. (ed.) Changing Structure of Global Food Consumption and Trade. Market and Trade Economics Division, Economic Research Service, U.S. Department of Agriculture and Trade Report, WRS-01-1. <https://www.ers. usda.gov/publications/pub-details/?pubid=40319> 10.7.2018.

Regmi, A., Deepak, M. S., Seale, Jr., J. L. \& Bernstein, J. (2001) Cross-country analysis of food consumption patterns. In Regmi, A. (ed.) Changing Structure of Global Food Consumption and Trade. Market and Trade Economics Division, Economic Research Service, U.S. Department of Agriculture and Trade Report, WRS-01-1. <https://www.ers.usda.gov/publications/pub-details/?pubid=40319> 20.7.2018.

Reynolds, K. (2015) Disparity despite diversity: social injustice in New York City's urban agriculture system. Antipode 47(1) 240-259. https://doi.org/10.1111/anti.12098

Royte, E. (2016) How 'ugly' fruits and vegetables can help solve world hunger. National Geographic March 2016. <http://www.nationalgeographic.com/magazine/2016/03/g/obal-food-waste-statistics/> 9.3.2017.

Sharma, P., Dwivedi S. \& Singh, D. (2016) Global poverty, hunger, and malnutrition: a situational analysis. In Singh, U., Praharaj, C., Singh, S. \& Singh, N. (eds.) Biofortification of Food Crops, 19-30. Springer, New Delhi. https://doi.org/10.1007/978-81-322-2716-8 2

Sengupta, S. (2017) How much food do we waste? Probably more than you think. The New York Times 12.12.2017. <https://www.nytimes.com/2017/12/12/climate/food-waste-emissions.htm/> 6.7.2018.

Slocum, R. (2006) Anti-racist practice and the work of community food organizations. Antipode 38(2) 327-349. https://doi.org/10.1007/978-1-137-03728-2_9

Slocum, R. (2008) Thinking race through corporeal feminist theory: divisions and intimacies at the Minneapolis Farmers' Market. Social \& Cultural Geography 9(8) 849-869. https://doi. org/10.1080/14649360802441465

Sonnino, R. (2016) The new geography of food security: exploring the potential of urban food strategies. The Geographical Journal 182(2) 190-200. https://doi.org/10.1111/geoj.12129

Sonnino, R. \& McWilliam, S. (2011) Food waste, catering practices and public procurement: a case study of hospital food systems in Wales. Food Policy 36(6) 823-829. https://doi.org/10.1016/j. foodpol.2011.09.003

Stefan, V., van Herpen, E., Tudoran, A. A. \& Lähteenmäki, L. (2013) Avoiding food waste by Romanian consumers: the importance of planning and shopping routines. Food Quality and Preference 28(1) 375-381. https://doi.org/10.1016/j.foodqual.2012.11.001

The Farmers Market Co. (2017a) Spotsylvania Farmers Market. <http://www.thefarmersmarket.co/ spotsylvania-farmers-market/>

The Farmers Market Co. (2017b) Fredericksburg Farmers Market. < http://www.thefarmersmarket.co/ fredericksburg-farmers-market/>

The Farmers Market Co. (2017c) SNAP EBT. <http://www.thefarmersmarket.co/snap-ebt/>

Turner, B. (2014) Cut-price 'ugly' supermarket food won't reduce waste - here's why. The Conversation 25.12.2014. <https://theconversation.com/cut-price-ugly-supermarket-food-wont-reduce-wasteheres-why-35375> 10.1.2018. 
U.S. Census Bureau (2016a) American factfinder: Fredericksburg City, Virginia. <https://factfinder. census.gov/faces/nav/jsf/pages/community_facts.xhtml?src=bkmk>

U.S. Census Bureau (2016b) Spotsylvania County, Virginia population estimates, July 1, 2016. <https:// wWw.census.gov/quickfacts/fact/table/spotsy/vaniacountyvirginia/PST045216?>

USDA-AMS-Local Food Research \& Development Division (2016) National count of farmers market directory listings. <https://www.ams.usda.gov/sites/default/files/media/National\%20Count\%20 of\%200perating\%20Farmers\%20Markets\%201994-2016.jpg> 5.7.2017.

Vecchio, R. (2009) European and United States farmers' markets: similarities, differences and potential developments. In Proceedings of the $113^{\text {th }}$ EAAE Seminar "A Resilient European Food Industry and Food Chain in a Challenging World," Crete, Greece, 3-6 September 2009. <http://ageconsearch. umn.edu/bitstream/58131/2/Vecchio.pdf> 16.6.2017.

Watson, M. \& Meah, A. (2012) Food, waste and safety: negotiating conflicting social anxieties into the practices of domestic provisioning. The Sociological Review 60(S2) 102-120. https://doi. org/10.1111/1467-954X.12040

Watts, D. C., Ilbery, B. \& Maye, D. (2005) Making reconnections in agro-food geography: alternative systems of food provision. Progress in Human Geography 29(1) 22-40. https://doi. org/10.1191/0309132505ph526oa

Wegmans Food Markets (2017a) Company overview. <https://www.wegmans.com/about-us/companyoverview.htmls

Wegmans Food Markets. (2017b) Near our stores. <https://www.wegmans.com/about-us/near-ourstores.htm/>

Winter, M. (2003) Geographies of food: agro-food geographies making reconnections. Progress in Human Geography 27(4) 505-513. https://doi.org/10.1191/0309132503ph446pr 